\title{
Corporate Taxation and Productivity Catch-Up: Evidence from
}

\section{European Firms}

\author{
Norman Gemmell ${ }^{\mathrm{a}}$, Richard Kneller ${ }^{\mathrm{b}}$, Danny McGowan ${ }^{\mathrm{c}}$, Ismael Sanz ${ }^{\mathrm{d}}$ and José F. Sanz-Sanz ${ }^{\mathrm{e} *}$
}

Version Date: $20^{\text {th }}$ April 2016

\begin{abstract}
This paper explores whether higher corporate tax rates reduce the speed with which small firms converge to the productivity frontier by lowering the after-tax returns to productivity-enhancing investments. Using data for 11 European countries we find evidence that their productivity catch-up is slower the higher are statutory corporate tax rates. In contrast, we find large firms are instead affected by effective marginal rates. Using the reduced form model of productivity convergence due to Griffith et al. (2009) our results are robust to a host of robustness checks and a natural experiment that exploits the 2001 German tax reforms.
\end{abstract}

Keywords: Productivity, taxation, convergence

JEL Codes: D24, H25, L11, O31

* We are very grateful to the editor, Peter Norman Sørensen, and three anonymous referees for excellent comments and suggestions. We thank seminar participants from the University of Exeter, ZEW (Mannheim) and the UK HMRC.

${ }^{a}$ Gemmell: Victoria University of Wellington, New Zealand; ${ }^{b}$ Kneller: (corresponding author), University of Nottingham, UK, Email: richard.kneller@nottingham.ac.uk; ${ }^{\mathrm{c}}$ McGowan: University of Nottingham, UK; ${ }^{\mathrm{d}}$ Sanz: Universidad Rey Juan Carlos, Spain. ${ }^{\text {e }}$ Sanz-Sanz: Universidad Complutense de Madrid, Spain. Kneller and McGowan gratefully acknowledge financial support from the ESRC under project no. RES-194-23-0003. Sanz-Sanz acknowledges support from project ECO2012-35572. 


\section{Introduction}

The large differences in the level of productivity that exist between firms within the same industry have stimulated what is now a significant body of research into the drivers of productivity change, and in particular the factors that encourage firms to catch-up with those on the productivity frontier. ${ }^{1}$ Common themes within this research have included whether non-frontier firms invest to improve their productivity in response to the presence of foreign multinational firms (see Görg and Greenaway, 2004, for a review), or intra-market (Foster et al., 2001) and import competition (Schmitz, 2005; Disney et al., 2003; Nicoletti and Scarpetta, 2005). We contribute to this literature by testing whether aspects of the domestic policy environment affect the productivity catch-up of firms.

Whilst convergence of productivity levels from below is a feature present in our cross-country firmlevel data, and has been found in other micro datasets by Bartelsman et al. (2008), Griffith, et al. (2009) and others, there is also evidence that the rate of catch-up differs significantly across firms. This suggests the presence of features of the economic environment that constrain the ability of some firms to make productivity-enhancing investments (PEIs). ${ }^{2}$ In this paper we investigate the role played by corporate taxation. The question we consider is therefore: does higher corporate taxation reduce the expected returns to PEIs, diminishing the ex-ante incentive for firms to invest thereby slowing their rate of productivity convergence? $?^{3}$

In his recent summary of the firm productivity literature Syverson (2011) argues that differences in productivity across firms arise from differences in the creation of new technologies through $R \& D$, as well as the quality of human and physical capital inputs, but also from 'soft technologies' such as management and organisation (Bloom and Van Reenen, 2007; Bloom et al., 2014). Traditionally research on the effects of

\footnotetext{
${ }^{1}$ Syverson (2004) shows that in the US firms near the top of the productivity distribution (the $90^{\text {th }}$ percentile) produce close to twice as much output from an identical amount of inputs compared to firms that are near the bottom of the productivity distribution (the $10^{\text {th }}$ percentile). In other countries these differences are even larger (Syverson, 2011).

${ }^{2}$ Evidence on other features of the domestic policy environment includes the effects of policy changes related to market regulation (Nicoletti and Scarpetta, 2005; Arnold, Nicoletti and Scarpetta, 2008), labour market flexibility (Petrin and Sivadasan, 2010) and trade liberalisation (Pavcnik, 2002; Bloom, Draca and Van Reenen, 2011). The evidence from this paper might be used to suggest that a wider range of aspects of the domestic policy environment are also relevant.

${ }^{3}$ This builds on the idea, known since Arrow (1962), that restrictions on the ability to appropriate the returns to innovations slow the rate of technological progress.
} 
taxation at the micro level has concentrated on its effects on firms' R\&D and tangible capital investments. The relationship between tax policy (mostly R\&D tax credits) and the volume, or the location, of R\&D across countries/US states is reviewed in Hall and van Reenen (2000), while Auerbach (2002), Hasset and Hubbard (2002), and Hines (2005) examine the relationship between taxation and capital investment. The conclusion from this literature has been that high statutory corporate tax rates reduce investment in physical capital by increasing the user cost of capital (Hasset and Hubbard, 2002). ${ }^{4}$ Where new vintages of physical capital embody technological progress this will reduce firm-level productivity and slow convergence.

The effect of changes to management practices and firm organisations on productivity opens the possibility that the effects of taxation on productivity are stronger than would be suggested by this existing literature on tangible capital investment and $R \& D$ and, additionally, that they may be affected by different measures of the corporate tax regime. For example, the measures of forward looking effective marginal tax rates constructed by Devereux and Griffith (2003) are applicable to an investment in plant and machinery, undertaken under alternative assumptions regarding the relevant rate of interest, inflation rate and method of financing (debt, equity) and which account for various depreciation allowances for different types of capital investment provided under the tax code. In contrast, changes to the way that a firm is managed usually involve an investment of managerial time to identify, organise and implement changes and does not qualify for tax credits or depreciation allowances. For investments of this type, the possibility is raised that the statutory corporate tax rate is the most empirically relevant measure of taxation. Further motivation for this view comes from Lee and Gordon (2005), Arnold et al. (2011), and Gemmell et al. (2011) who produce evidence that macro-level measures of TFP are affected by tax variables including the statutory corporate tax rate and in Gemmell et al. (2015) that the statutory rate has a stronger and more robust effect on growth than the Devereux and Griffith (2003) measures of taxation.

Economic theory also motivates a search for evidence that corporate taxes elicit heterogeneous productivity responses depending on firm characteristics. Again drawing on the capital investment literature, Egger et al. (2014) develop a tractable model of corporate taxes and firm-level investment. Depending on their size, firms respond in different ways to different forms of taxation. Small (innovative) firms are credit

\footnotetext{
${ }^{4}$ Further detail on the user cost of capital is provided for the interested reader in Appendix D to this paper.
} 
constrained which makes investment sensitive to cash-flow and the amount of collateral they may post. ${ }^{5}$ Because small firms rely heavily on retained profit for investment, higher tax rates reduce internal funds and lower levels of investment.

Our conclusions regarding the effects of corporate taxation on the productivity convergence of small firms are reached by undertaking two complementary pieces of empirical analysis. In the first part we exploit variation in the tax rates faced by firms in different countries over time. Using the reduced form model of firm productivity convergence by Griffith et al. (2009), and an unbalanced panel of manufacturing and service sector firms from 11 European countries over the period 1996 to 2005, we find that higher statutory corporate taxation significantly slows the productivity growth of small firms that are furthest from the productivity frontier. In contrast we show that these effects do not apply to large firms, even those with a greater scope for imitation. We do find however some evidence that these large firms are affected by higher effective marginal tax rates, whereas small firms are unaffected, and there is an effect from personal income taxation on both types of firms. This final result is consistent with the view that the productivity investments of firms are dependent on the actions of workers though management and organisational change. Together these results highlight an important heterogeneity in the effects of taxation across countries and additionally across firms within the same country according to the size of their productivity gap relative to the productivity frontier. In turn this implies that the effects of changes to taxation on aggregate productivity growth will depend upon the level of taxation, the structure of taxes, the numbers of small firms and the average productivity gap.

The second component of the empirical evidence we provide exploits a quasi-natural experiment in which there was a 13 percentage point reduction in corporate tax rates in Germany between 2000 and $2001{ }^{6}$ The reform is plausibly exogenous with respect to firm productivity as it was designed to adapt the German tax system to the EC Common Market (Becker et al., 2006). We again find evidence consistent with the view that higher tax rates slow productivity convergence for small firms. Following the reduction in corporate tax rates, productivity growth in small German firms increased compared to a counterfactual of small firms in

\footnotetext{
${ }^{5}$ See Beck et al. (2008) and Aghion et al. (2007) for evidence that small firms are more likely to be credit constrained than large firms. Hubbard (1998), Beck and Demirguc-Kunt (2006) and Aghion et al. (2007) show that firm growth is limited by financial frictions.

${ }^{6}$ In this regard, the paper complements the evidence of the effects of changes to corporate taxation and depreciation allowances on investment using a natural experiment approach by Cummins et al. $(1994,1996)$ and House and Shapiro (2008).
} 
those European countries where there was no tax change over this period (Sweden, Spain and the UK). These effects are economically significant. Our results suggest that the effect of the reduction in the corporate tax rates in Germany was to raise the productivity growth rate for a small firm with the mean level of productivity ( $83 \%$ of the frontier firm) by 1.7 percentage points relative to the counterfactual.

Importantly, our econometric tests take several steps to isolate causal inferences. In our setting endogeneity bias may arise due to omitted variable bias or from reverse causality if there is little deadweight loss from taxing firms that persistently lie far from the productivity frontier. To eliminate these potential sources of bias our cross-country approach includes country, industry and year dummies and in robustness test country-time and industry-time dummies that net out any time-varying shocks that systematically correlate with changes to tax rates. Furthermore, we use the natural experiment to drive at causality.

As discussed in the next section, the evidence we provide is consistent with that presented by Arnold et al. (2011) and Masso et al. (2013). They find evidence respectively that, for European firms, higher corporate taxes slow productivity growth in more profitable industries, and that for Estonian firms corporate tax cuts provoke a significant increase in investment spending with the effect most pronounced among small firms.

In the following section we outline the previous literature that motivates our analysis and the econometric model that we adopt to estimate the effects of corporate taxation. Section 3 describes key characteristics of the data. Section 4 details the main results of the paper. Sub-section 4.1 describes the baseline estimates and we use sub-sections 4.2 and 4.3 to test their robustness. Sub-section 4.4 reports on the second component of the empirical evidence; namely, the effect of the German tax reforms. Finally, we draw some conclusions from the study in Section 5.

\section{Previous Literature and Econometric Strategy}

\subsection{Previous Literature}

Macro-dynamic modelling has made great strides in recent years in analysing the potential impact of changes in tax policy on a variety of macro variables including output levels and the transitional/long-run rates of output growth (e.g. Barro et al., 1995; Turnovsky, 2004). While some of these models have been 'tested' by calibrating them to specific country (usually the US) characteristics, in general empirical tests of such models have relied on aggregate level regressions for panels of different country samples, (see, for example, Kneller et al., 1999; Bleaney, et al 2001; Arnold, 2008; Romero-Avila and Strauch, 2008; Romer 
and Romer, 2010). These studies have increasingly found evidence consistent with significant adverse longrun impacts from increases in various 'distortionary' taxes including corporate tax rates. Theories of taxation and growth by Peretto (2007), and empirical studies by Lee and Gordon (2005), Arnold et al. (2011) and Gemmell et al. $(2011,2015)$ have also shown that these aggregate growth effects occur through productivity, in addition to any effect on the accumulation of tangible and human capital.

Aggregate productivity growth occurs as a consequence of the replacement of low-productivity firms by new entrants with higher productivity in a process often called Schumpeterian 'creative destruction'; from the reallocation of resources to high productivity firms (known as the between effect); and as the productivity of surviving firms improves (known as the within effect). Foster et al. (2001) show that all contribute to aggregate growth, although the within and between components typically make the largest contributions. The research linking these aggregate productivity and growth effects of taxation to changes at the micro level has concentrated on a small number of the potential mechanisms. In this paper we focus on the effects of taxation on within firm productivity change. ${ }^{7}$ Recent evidence for firm-level effects of taxation has focused more on firm entry and exit rates, see Da Rin et al. (2011) and Djankov et al. (2010), while Carroll et al. (2000) examine the effects of US tax reforms in the 1980s on the investment and employment decisions of small businesses, finding significant effects.

Syverson (2011) provides a detailed discussion of the determinants of within firm productivity change, including that on the quality of inputs (both human and physical capital), the creation of new technologies through R\&D and more recent evidence on management quality and managerial change (Bloom and Van Reenen, 2007, 2010). As already discussed, research on the effects of taxation has concentrated on direct effects of $R \& D$ and capital investments. Corporate taxes for example can raise the user cost of capital and reduce the incentive to invest.

Empirical evidence of a direct relationship between taxation and firm productivity is more limited with evidence currently confined to Arnold et al. (2011), Masso et al. (2013) and Bridgman et al. (2009). The regression-based approach adopted by Arnold et al. (2011) and Masso et al. (2013) is most similar to the work

\footnotetext{
${ }^{7}$ The database from which we draw our information on firms, Amadeus, provides incomplete information on the entry and exit process. This prevents us from additionally exploring this channel using this data.
} 
in this paper. Arnold et al. (2011) use a large sample of European firms and report that firms in industries that are more profitable are more affected by corporate taxation. Masso et al. (2013) use a significant change to corporate profit taxation in Estonia at the start of the century as a natural experiment. They find that compared to a counterfactual of firms in Latvia and Lithuania the productivity and investment behaviour of small firms were particularly affected by changes to profit taxation that occurred.

Finally, Bridgman et al. (2009) examine the productivity effects of regulations in the US sugar market. Whilst the industry regulation they study extends beyond taxation to include restrictions on the entry of new sugar beet refiners and imports, one aspect of the policy environment they consider is the application of an income tax on sugar beet refiners (to pay for a subsidy for sugar beet farmers). They find that the productivity of sugar refiners fell as a result of the regulation of this market. This occurred in part because the share of industry revenues that went to the refiners fell because of the tax. As a result, the authors argue, refiners had little incentive to invest to maintain their equipment, which lowered their productivity.

\subsection{Econometric Strategy}

We take two complementary approaches to explore the link between productivity catch-up and corporate taxation. To capture the various effects of taxation on the productivity growth of firms using crosscountry data our first approach draws on Griffith et al. (2009) and estimates a reduced form model with an error correction structure set out in equation (1), where A denotes productivity, $i$ denotes firms, $j$ industries, $c$ countries, $F$ is the frontier, and $t$ time

$$
\begin{aligned}
& \Delta \ln A_{i j c t}=\alpha_{0}+\alpha_{1} \Delta \ln A_{F j c t}+\alpha_{2} \ln \left(\frac{A_{i j c t-1}}{A_{F j c t-1}}\right)+\alpha_{3} \ln \left(\frac{A_{i j c t-1}}{A_{F j c t-1}}\right) \times T_{c t}+\alpha_{4} \ln \left(\frac{A_{i j c t-1}}{A_{F j c t-1}}\right) \times Z_{j}+\alpha_{5} \mathrm{~T}_{c t}+ \\
& a_{6} X_{i j c t}+\gamma_{c}+\gamma_{j}+\gamma_{t}+\varepsilon_{i j c t} .
\end{aligned}
$$

The parameter $\alpha_{1}$ in equation (1) captures the instantaneous effect of changes in the productivity frontier (denoted $\Delta \mathrm{A}_{\mathrm{F}}$ ) on all firms and $\alpha_{2}$ the speed at which firms can close the gap with the best firms. We anticipate that $\alpha_{2}$ will be negative: the greater the size of the initial productivity gap of firm $i$ relative to the frontier in the previous time period the faster a firm grows in this time period. Following evidence from Bartelsman et al. (2008) we assume in equation (1) that firms benchmark themselves against the productivity level of the domestic leader in their industry. The country-industry frontier is considered the relevant 
benchmark because of differences in the appropriateness of different management practices to different country and industry settings. ${ }^{8}$

We allow taxation to affect productivity growth directly (captured by $\alpha_{5}$ ), because it affects the decision to invest in the creation of new knowledge such as $R \& D$, but also the catch-up process (captured by $\left.\alpha_{3}\right)$. It is the effect on the rate of catch-up where we concentrate our analysis. We anticipate that these constrained and highly taxed firms will make fewer, smaller and less-risky investments to improve their productivity (Arnold et al., 2011), so that the speed of convergence to the frontier will be slower. In this case the coefficient $\alpha_{3}$ will be positive. Alternatively, if higher taxation encourages firms to work harder to improve productivity then $\alpha_{3}$ will be negative. In our empirical work we focus on incorporated firms so that it is the impact of corporate tax rates that are most relevant. We consider possible effects from personal income taxes in section 4.3. Given the broad range of determinants of productivity and the predictions in Egger et al. (2014), in our initial investigations we use a basic measure of corporate taxation, namely the statutory tax rate. We explore the potential for broader measures, including measures of the effective tax rate based on investments in plant and machinery in Section 4.3. Finally motivated by evidence in Egger et al. (2014) that the effects of taxation are likely to differ across firms of different sizes we focus our analysis on small firms. We test the sensitivity of our results to the definition of smallness in Section 4.2.

We also include a number of other control variables within equation (1), although limits on space prevent us from reporting all of these within the tables. In equation (1) we include a set of interactions between the TFP gap and industry profitability which we label as $Z_{j}$. This captures the fact that the speed of convergence may depend on industry profitability (Arnold et al., 2011). Here we hypothesise that greater profitability might act as a spur to make PEIs. To ensure that we capture the inherent profitability of an

\footnotetext{
${ }^{8}$ Bartelsman et al. (2008) find that firms converge more quickly to the domestic-industry frontier than the global-industry frontier. This assumption has the convenient property that it does not require that we transform the cross-country data to a common currency. Such comparisons are known to be sensitive to assumptions about the choice of exchange rate (Bartelsman et al., 2008). The exclusion of the global frontier is, arguably, most plausible for small firms. We test the robustness of our results to this assumption by including in regression 9 industry-time dummies, which capture movements of the global-industry frontier.
} 
industry rather than any effect that higher corporate tax rates in a country might have on this variable, we follow Arnold et al. (2011) and use (time invariant) industry-level data on profitability for the US as a proxy. ${ }^{9}$

To control for other factors that affect productivity but which are not accounted for in the above model we include a set of variables denoted by $X_{i j c t}$ in equation (1). Within this we include the ratio of government expenditure to GDP and the ratio of government revenue to GDP. Finally we also include a set of country, industry and time dummies. To further establish the robustness of our findings in Section 4.2 we extend the set of control variables to include country-time and industry-time dummies and then firm fixed effects.

The second approach we use to identify the effects of taxation on the productivity convergence of small firms is to exploit, for identification purposes, a large change in the German corporate tax rate between 2000 and 2001. These productivity growth effects are compared to a counterfactual of firms from Spain, Sweden and the UK where there were no changes to corporate tax rates over the years 1999 to 2002 . The high degree of synchronization in business cycles across European countries reported by Alfonso and Sequeira (2010), Degiannakis et al. (2014) and Gayer (2007) ensures that economic conditions within the treatment and control groups are similar and further supports this choice. ${ }^{10}$

The estimating equation used in this section is laid out as equation (2) and takes on the form of a difference-in-differences regression.

$$
\begin{aligned}
& \Delta \ln A_{i j c t}=\beta_{1} \Delta \ln A_{F j c t}+\beta_{2} \ln \left(\frac{A_{i j c t-1}}{A_{F j c t-1}}\right)+\beta_{3} \ln \left(\frac{A_{i j c t-1}}{A_{F j c t-1}}\right) \times \Delta T_{c t}+\beta_{4} \ln \left(\frac{A_{i j c t-1}}{A_{F j c t-1}}\right) \times T_{c, 1999}+ \\
& \beta_{5} \ln \left(\frac{A_{i j c t-1}}{A_{F j c t-1}}\right) \times Z_{j}+\beta_{5} T_{c t}+\beta_{6} X_{i j c t}+\gamma_{i}+\gamma_{t}+\varepsilon_{i j c t} .
\end{aligned}
$$

\footnotetext{
${ }^{9}$ The US is chosen as the country from which to derive this industry variable as its firms are subject to lower tax rates and fewer policy restrictions compared those in Europe and because it is not included in the sample, thereby reducing endogeneity concerns. Information on the profitability of industries is calculated from the 2002 U.S. Benchmark Input-Output Data Table (U.S. Bureau of Economic Analysis, 2002). For each industry at the 2-digit ISIC level a profitability ratio is calculated from data on gross operating surplus divided by value added; this is applied to the whole period of our analysis, 1995-2005. As $Z_{j}$ is time invariant and industry specific any direct effects of this variable are captured by the industry fixed effects. In Appendix regression C7 we replace industryprofitability with a measure derived from the dataset and provide summary statistics in Appendix Table B1. It would appear this choice has no bearing on our conclusions for taxation.

${ }^{10}$ Arguably the extent of business cycle synchronisation among those EU countries may have increased over our sample period (to 2005) but, if so, it would not obviously impact on our treatment and control group comparisons.
} 
Equation (2) retains much of the structure of equation (1) despite the change in identification strategy. For example the parameter $\beta_{1}$ captures the instantaneous effect of changes in the productivity frontier on all firms and $\beta_{2}$ the speed at which firms can close the gap with the best firms. However, some changes to the tax variable are necessary. The tax variable now appears in two places in equation (2). The coefficient $\beta_{3}$ captures the effect of changes in taxation for small German firms and therefore represents the main variable of interest in this regression. To capture the effect of differences in tax rates across countries before the 2001 German tax changes we additionally include the interaction between the TFP gap and tax rates fixed at their pre-reform values (the value in 1999). The coefficient $\beta_{4}$ captures what would have happened to productivity growth if Germany had left its corporate tax rates unchanged. We anticipate the signs on both of these variables to be positive. The remaining control variables are chosen so as to be consistent with equation (1), except we follow standard practice in the estimation of difference-in-differences regressions and include firm fixed effects. ${ }^{11}$

Our research design employs multiple strategies to pin down a causal relationship between tax policy and productivity convergence. Firstly, we estimate equation (1) using country, industry and year fixed effects that eliminate the confounding influence of omitted variables that are unobservable to the econometrician but correlate with tax policy. Second, the German natural experiment exploits an exogenous shock to tax policy and leverages the fact that this affected small German firms but not those in the control group.

\section{Data Description and Summary}

Our firm-level data is taken from the Amadeus database (Bureau van Dijk) and covers 11 European countries for the years 1995-2005. We provide greater detail on the construction of the dataset and measures of TFP in the on-line Appendix A, providing only a brief description here. As in Arnold et al. (2011) we restrict the analysis to firms in manufacturing and service sectors (NACE 15-93) and exclude firms with missing data and obvious key punch errors. We also exclude observations from the agricultural, forestry and mining sectors as well as service sectors such as education and health services where public provision is more likely, and corporate taxation is usually not applicable.

\footnotetext{
${ }^{11}$ The firm fixed effects are perfectly collinear with country and industry dummies from equation (1) and so we do not include these. We continue to include time effects in this equation.
} 
To construct measures of productivity we estimate a separate production function for each countryindustry pair, such that firms' technologies can differ by country and industry. We then estimate TFP applying the semi-parametric method proposed by Levinsohn and Petrin (2003). This method allows the production function input parameters to be estimated while allowing for the possibility of an endogenous response of productivity to unobserved shocks. ${ }^{12}$ The productivity frontier in each country-industry time period is approximated by the productivity of firms that lie above the $95^{\text {th }}$ percentile of the TFP distribution. The $95^{\text {th }}$ percentile rather than the maximum value of TFP is chosen to represent the frontier in order to reduce the possibility that extreme data points caused by measurement error affect the results. The lagged TFP gap for each firm in each year is then constructed as the $(\log )$ of the ratio of the level of TFP of each firm to the relevant country-industry productivity frontier. As a consequence of measuring the lagged TFP gap we require at least 2 observations for each firm and therefore the data period for estimations covers the period 1996 to 2005. In order to concentrate on the determinants of productivity catch-up, we further restrict the analysis to non-frontier firms. ${ }^{13}$ This sample covers over 226,000 observations on 54,787 firms.

The country coverage differs, depending upon data availability within the Amadeus database. The larger European countries are particularly well represented. There are around 88,000 observations for Italy, 8,000 observations for France, 23,000 for Germany, 48,000 for Spain and 32,000 for the UK. Around 88\% of all observations are therefore from these 5 countries. The panel dimension of the data is relatively short and is unbalanced across time. The loss of firm information is greater the further we move away from the base year of 2003 (see Appendix A for more details). There are over 40,000 observations in each of the years 2003, 2004 and 2005 but less than a thousand observations in 1996 and 1997. The number of observations per year is displayed in Table 1, while the number of observations per country can be found in Table 3 .

\footnotetext{
${ }^{12}$ We follow Griffith et al. (2009) in using Levinsohn and Petrin (2003) as the benchmark TFP estimation and restrict Olley and Pakes (1996) for a robustness check since the latter methodology does not allow for a flexible production technology and the theoretical model does not incorporate productivity catch-up across firms, which is also a central feature of our empirical framework. The Levinsohn and Petrin (2003) estimator uses intermediate inputs as investment proxies.

${ }^{13}$ In Appendix regression $\mathrm{C} 1$ we include frontier firms in the sample. As in the rest of the paper the frontier is defined at the countryindustry level. The results are robust to this change.
} 
In Table 2 we report basic summary statistics for the rate of TFP growth across firms and countries, along with the growth rate of the productivity frontier. We provide summary statistics on all of the variables included in the estimations in on-line Appendix B. In Table 2, to ease the interpretation of the data we report the TFP of the average firm expressed as a percentage of the productivity frontier rather than the logged value we use in the estimation.

The average rate of TFP growth in the sample is 2.7 per cent per annum. This is faster than the growth rate of the productivity frontier (average rate of growth 0.6 per cent per annum), which suggests that the average firm converges towards the frontier over time. Finally, across the sample the average TFP of a firm compared to its domestic-industry productivity frontier is 79 per cent. To put this differently, the TFP gap of the average firm compared to the productivity frontier is 21 per cent.

In Table 3 we provide the distribution of relative TFP by country, the separate mean values for small and large firms, as well as further detail on the distribution of TFP. ${ }^{14}$ The evidence from this table suggests there is considerable heterogeneity in the size of this gap across countries. For example, firms in Germany operate consistently closer to the domestic technological frontier than firms in France or the UK. ${ }^{15}$ The average firm in Germany has an estimated TFP that is 88 per cent of the best firms there, whereas for France the average firm has a TFP that is 61 per cent of the best firms. For the UK the figure is 79 per cent. The average TFP of small firms is below that of large firms in every country except Italy and Portugal. In some cases the difference between the TFP for small firms and the average across all firms is large. In Germany for example, the average TFP of large firms compared to the frontier firm is 94 per cent, versus 83 per cent for small firms.

Table 3 also provides information on the dispersion of TFP across firms in each country. It would appear from this table that France, Italy and the UK have a longer tail to their TFP distributions compared to

\footnotetext{
${ }^{14}$ Small firms are defined as those with fewer than 20 employees. Firm size is measured by the number of employees in that year. In regression $\mathrm{C} 2$ in the Appendix we fix firm size over the sample period. This has no bearing on the results. The choice of 20 employees is chosen to maintain a reasonable number of observations in both groups. The robustness of this is tested in sub-section 4.2 .

${ }^{15}$ As the production function is estimated separately for each country and industry the estimates of TFP do not provide information on the level of TFP across countries or industries. The results cannot therefore be used to determine whether firms in Germany are more or less productive than those in France for example.
} 
Germany. The firm at the $25^{\text {th }}$ percentile of the TFP distribution has a TFP level that is 85 per cent of the most productive firms in Germany, whereas in France it is 60 per cent, 65 per cent in Italy and 69 per cent in the UK. According to Table 3 the weakest TFP performance occurs in Austria, the Czech Republic and Denmark, although these are also amongst the countries for which we have least information. ${ }^{16}$ Here the TFP of the average firm compared to the productivity frontier in these countries is 35,51 and 50 per cent respectively.

\section{[Insert Table 1] [Insert Table 2] [Insert Table 3]}

We use the statutory corporate tax rate as our main measure of taxation, which we obtain from EUROSTAT, Taxation Trends in the EU. In sub-section 4.3 we test the robustness of the results for this variable to the use of the effective marginal tax rate for an investment in plant and machinery, which we obtain from the Centre for Business Taxation at the University of Oxford, and the top marginal personal income tax rate from EUROSTAT, Taxation Trends in the EU. The effective rates are hypothetical forward looking marginal rates applicable to specified investment in plant and machinery undertaken under alternative assumptions regarding, for example, the relevant rate of interest, inflation and method of financing (debt, equity). They also account for various depreciation allowances for different types of capital investment provided under the tax code for each country. These are available for each year for all of the countries in our sample although only for the years 2002 to 2005 for the Czech Republic and 1996 to 2005 for Spain.

In Table 4 we report the statutory corporate, personal income and effective marginal tax rate for each country averaged between 1995 and 2005. According to the information presented in the table, the highest average corporate tax rates are in Germany, 45.5 per cent, and Italy, 43.3 per cent. The corporate tax rates in the remaining countries range between 28 per cent (Sweden, Finland) and 37 per cent (France). Also important for the effects we identify are the changes in taxation across years. The corporate tax rate has fallen over time in most countries in the sample, with the largest falls in Germany (18 percentage points), Czech Republic and Italy (15 percentage points), Portugal (12 percentage points) and Austria ( 9 percentage points). In contrast in Spain and Sweden the corporate tax rate in 2005 was the same as in 1995, and in Finland it was 1 percentage point higher. Of the countries for which we have most data, the yearly changes in the rate of

\footnotetext{
${ }^{16}$ In regressions $\mathrm{C} 4$ and $\mathrm{C} 5$ in Appendix Table $\mathrm{C} 1$ we consider the robustness to the exclusion of countries with very few observations. Regression C4 excludes the Czech Republic and C5 additionally excludes observations from Austria, Denmark and Portugal.
} 
corporate taxation are generally relatively modest, of the order of 2-4 percentage points. An exception is Germany where the tax rate was reduced by 13 percentage points to 38 per cent between 2000 and 2001. We focus on the effects of the tax reform in Germany as a test of the robustness of our findings in sub-section 4.4.

Significant changes across time are evident for the other measures of taxation reported in Table 4 . The top personal income tax rate fell by 37 percentage points between 1995 and 2005 in Denmark and there were other large changes in France, Germany and Spain. Comparing the statutory corporate tax rate with the effective marginal rate indicates much smaller cross-country variation in the latter owing to differences in the investment allowances that can be used to offset taxation in many countries. The cross-time changes in the effective marginal tax rate on investment in plant and machinery have typically been smaller than those for the statutory rate and there are also some differences in their timing. The correlation between these two tax measures is 0.576 , indicating that they may be capable of capturing quite different variation within the data.

[Insert Table 4]

\section{Empirical Evidence}

In this section we report the results from the estimation of equation (1) and provide a discussion of the magnitude of the estimated effects. Some general issues of robustness are explored in Section 4.2 and the effects of alternative tax variables are considered in section 4.3. The effects of the 2001 tax reform in Germany can be found in Section 4.4. As a reminder, in all of the regressions we include control variables for the general level of government expenditures and tax revenues alongside differences in the rate of convergence due to industry profitability. In the estimation of equation (1) we also control for country, industry and time effects except when we report regression 9, where we replace these with country-time and industry-time effects and regression 10 where we include firm fixed effects. To conserve space we report only the main variables of interest and indicate in the table which other variables have been included.

\subsection{Baseline Estimates}

The baseline estimates include regressions 1 to 3 in Table 5 . In regression 1 we use the full sample of firms available to us, regression 2 includes observations for small firms only (fewer than 20 employees) and regression 3 reports the same regression but where the sample is restricted to large firms (20 or more employees). Before we discuss the effect that these changes to the sample have for the tax variable we begin with a discussion of results for the other control variables reported in the table. 
The first two variables listed in the table measure the effect of growth of the technological frontier and the rate of productivity catch-up (denoted TFP gap). The results for these compare favourably with those from elsewhere in the literature. Firstly, growth of the domestic-industry productivity frontier is found to have positive spillover effects on the growth of firms operating behind the frontier (see Griffith et al. 2001, 2003 for similar evidence). The magnitude of the coefficient indicates that when the frontier grows by 1 per cent, productivity in non-frontier firms grows by 0.343 percentage points. Comparing across regressions 2 and 3 suggests that the effect is somewhat stronger for small compared to large firms, although both are statistically significant.

The results in Table 5 also indicate productivity convergence is present in the data. The rate of productivity growth is increasing in the relative productivity gap between the firm and the (domestic-industry) frontier. For those firms with a large TFP-gap relative to the frontier in the previous period (firms with low relative TFP) the easier it is to imitate from others and therefore catch-up with the best firms over time. Similar evidence exists at the aggregate (Bond et al., 2001), industry (Griffith et al., 2003) and firm level (Griffith et al., 2009). According to the summary statistics in Table 3 the average productivity of non-frontier firms relative to the productivity frontier is 79 per cent. For this average firm, and using the parameter estimates from regression 1 and mean values for taxation and profitability, the rate of productivity growth would be 1.8 percentage points per annum faster than a firm with a productivity level 85 per cent of the frontier firm, and around 3.2 percentage points per annum faster than a firm with a productivity level 90 per cent of the frontier firm. ${ }^{17}$

\section{[Insert Table 5]}

There is also evidence in the table that higher taxation slows the rate of productivity catch-up for some firms. The TFP gap variable interacted with the corporate tax rate for all firms (TFP gap $\times$ Corp. Tax.) is statistically significant and positive in regressions 1 and 2 but not regression 3 . As a reminder, regression 2 restricts the sample to small firms only. In regression 3 where we restrict the sample to include firms with 20 or more employees (labelled large firms) the coefficient on the tax-TFP gap variable remains positive but is

\footnotetext{
${ }^{17}$ These results relate to an 'average' firm at a given distance from the frontier, and many additional factors are likely to affect the distribution of firms' productivity catch-up around that average, such as variations in firms' absorptive capacity or constraints on their ability to invest. Where this leads some firms to exit their industry it is likely to be imperfectly captured in the current dataset.
} 
far from being significant at conventional levels. A test comparing the effect of taxation between small and large firms confirms this difference. ${ }^{18}$ These results are consistent with an interpretation that small firms are constrained in their ability to make productivity-enhancing investments and are therefore sensitive to corporate tax rates. ${ }^{19}$ The existing theoretical evidence suggests that this occurs because higher taxation reduces the net present value (NPV) of future investments for small firms, such that they invest less in productive technologies. ${ }^{20}$ Large firms are unaffected, possibly because the types of productivity investment they undertake are different from small firms, or due to better tax planning. ${ }^{21}$

The effect of all this is to slow the rate of convergence of small firms, rather than prevent it altogether, and within some countries for small firms to grow less quickly than large firms despite typically having lower productivity. In countries, such as Germany, the estimation results combined with the information in Table 3 indicates that the productivity differences between small and large firms and with the productivity frontier narrow over time: the rate of productivity catch-up for the average large firm (average TFP $94 \%$ of the frontier) would be $2.5 \%$ per annum, compared to $4.6 \%$ per annum for the average small firm (average TFP gap $83 \%$ of the frontier) when including the effects of taxation. This contrasts with countries where the initial TFP gap is much closer, such as Spain. Here the convergence slowing effects of taxation are such that

\footnotetext{
${ }^{18}$ We conduct this test by pooling small and large firms and allowing the tax-TFP gap to differ between them (we also allow for differences in the rate of convergence). The coefficient for the effect of taxation for all firms is equal to 0.112 with a standard error of 0.109 , while the estimated coefficient for the interaction of the tax-gap with small firms is 0.322 with a standard error of 0.111 . Only the latter is significant at conventional levels confirming a difference in the effect of taxation between small and large firms.

${ }^{19}$ We consider the possibility that the results for taxation are affected by endogeneity bias by using an instrumental variable approach. We report the results from this regression as regression C3 in Appendix C, while further detail on their construction can be found in Appendix D. The results are robust to using this alternative estimation method.

${ }^{20}$ In unreported regressions we also investigated whether catch-up with the frontier is driven by firing less-productive workers. We estimate equation (1) using the number of employees as the dependent variable. The corporate tax-TFP gap coefficient is statistically insignificant indicating catch-up was not due to labour adjustment.

${ }^{21}$ This difference in the effect of taxation is of interest as it would suggest that in order for omitted variable bias to explain these findings the omitted variable must be correlated with the convergence of small firms but not large firms. Whilst this can never be ruled out, it would at least appear to severely limit the possible candidates for such a variable.
} 
productivity growth of small firms is below large firms. In these countries small firms continue to catch up with the productivity frontier, but the average small and large firm are diverging from each other.

In Table 6 we provide further detail on the magnitude of the tax effects, using the coefficient estimates from regression 2 to compare the rate of productivity growth of small firms in different tax settings. In the table we compare the growth rate of a firm with a productivity level equal to $75 \%, 85 \%$ and $95 \%$ of the frontier in their country at different rates of corporate taxation $(25 \%, 30 \%, 35 \%, 40 \%$ and $45 \%)$ compared to a firm that faces a corporate tax rate of just $20 \%$. These tax rates are chosen as representative of the corporate tax rates across the countries that make up our sample. The tax rate of $40 \%$ is close to that for Italy at the end of the sample period, France had a tax rate of $35 \%$ by the end of the period, the UK around $30 \%$ and Austria $25 \%$. No country in our sample had a statutory corporate tax rate of $20 \%$, but this figure is an upper bound on the tax rates found in low-tax European countries not in the sample, such as Ireland and Switzerland.

The table shows that for a small firm in a country with corporate tax rates of $25 \%$ and with a productivity level $75 \%$ of a frontier firm, productivity growth is 0.43 percentage points per annum slower compared to that estimated for the same firm facing a corporate tax rate of $20 \%$. In a high tax country, where the corporate tax rate is $40 \%$, productivity growth is 1.73 percentage points slower than for a firm facing a corporate tax rate of $20 \%$. The effects of taxation become quantitatively less important the closer the small firm is to the productivity frontier. For firms with a productivity level equal to $95 \%$ of the frontier, operating in a low tax environment (the corporate tax rate is $25 \%$ compared to $20 \%$ ) the difference is only 0.19 percentage points. From this it would appear that differences in the size of the TFP-gap matter more than differences in taxation for the growth rate of productivity in small firms, although both play a role.

\section{[Insert Table 6]}

\subsection{Robustness of baseline estimates}

In regressions 4 to 8 in Table 5 and regressions 9 and 10 in Table 7 we establish the initial robustness of these findings. In regressions 4,5 and 6 we redefine small firms as those with employment below 10 (regression 4), 30 (regression 5) and 50 employees (regression 6). The results are very stable across these regressions, and indicate little sensitivity to this choice. We find consistent evidence that the rate of convergence for small firms is slowed by higher corporate tax rates, which are strongest when we concentrate on the smallest firms in regression 4. 
In regressions 7 and 8 we test for the robustness of the results from regression 2 to alternative measures of TFP. As described in Section 3 these use different methods to address the endogenous response of productivity to unobserved shocks. We report results using the methodologies of Olley and Pakes (1996) (regression 7) and Wooldrige (2009) (regression 8). Using these alternative measures of TFP we again find evidence that firms' productivity growth is affected by the size of the productivity gap to the country-industry frontier and that the rate of catch-up is slower the higher is the corporate tax rate. The interaction between the productivity gap and the statutory corporate tax rate is again positive and statistically significant.

Other features of the policy environment, not accounted for in the regression, are a separate concern surrounding the effect of unobservable variables on the measurement of TFP. If these are correlated with taxation and affect the rate of productivity convergence across countries then the estimates in Table 5 might be biased. In their empirical modelling Arnold et al. (2011) control for time-varying country policy variables using country-time effects. In Table 7 regression 9 we follow this approach. The inclusion of country- and industry-time dummies has little impact upon the results. ${ }^{22}$ The tax variable remains significant and positive.

A similar finding occurs when we include firm fixed effects in the model in regression 10. Thus far we have assumed that the investments a firm makes in its productivity will move it closer to the domesticindustry frontier. Regression 10 relaxes this assumption and allows for the possibility that the returns to productivity enhancing investments may be constrained by difficult-to-observe, firm-specific characteristics such as the managerial ability of the firm (Bloom and Van Reenen, 2007, 2010). Despite the change in modelling strategy, the key results remain unchanged. Higher corporate tax rates can slow the rate of productivity convergence. ${ }^{23}$ The magnitude of this effect is larger in this regression than previous estimates in the tables. This likely occurs because of the inclusion of firm fixed effects alongside the lagged dependent

\footnotetext{
${ }^{22}$ In Appendix regression C8 we test whether omitted determinants of technological change within the firm might explain our findings by including intangible assets as a proxy for R\&D. Despite a lack of information on intangible assets for many firms, our results are robust to including this additional control variable. In Appendix E we provide detail on the tax treatment of R\&D across countries.

${ }^{23}$ In regression 10 the coefficient on the TFP gap variable is larger than 1. However, at the mean value of profitability (26.7) and the mean value of corporate income taxation $(0.35)$ the convergence parameter is equal to $-0.759(=-1.855+(26.7 \times 0.0053)+(0.35 \times$ 2.727)), confirming that the convergence path is not explosive.
} 
variable in the form of the measure of the TFP-gap, which leads to a downward bias in the estimated coefficient on the lagged dependent variable (Nickell, 1981).

\subsection{Additional Tax Variables}

The review by Syverson (2011) makes clear that cross-firm differences in productivity are explained by a wide range of factors including the quality of machinery and equipment such as ICT, as well as human capital, $R \& D$ and management or organisational differences. In our use of the statutory corporate tax rate we have ignored the effect of deductions against taxable profits that can be made for capital investments which may affect productivity (Devereux and Griffith, 2003) as well as the effect of personal income taxation on the efficiency of workers. This raises the question of whether an alternative measure of corporate taxation, such as the effective marginal tax rate, or other types of taxation, such as the personal income tax rate, are better able to capture the variation in productivity convergence that we focus on.

To model the effects of personal income taxation we include an interaction between the top personal income tax rate and the productivity gap variable in regression $11 .{ }^{24}$ In regression 12 we replace our measures of the statutory corporate tax rate with forward looking effective rates based on the methodology of Devereux et al. (2002). Finally in regression 13 we repeat regression 12 but consider only large firms.

We find some interesting results from this exercise. For personal income taxation we find evidence that this also slows the rate of convergence, the estimated coefficient is again positive and statistically significant. This occurs whether our focus is on small firms (regressions 11 and 12) or large firms (regression 13). We note however there is some sensitivity of this finding in Table 8 further below, where we find the reverse outcomes for personal income taxation. ${ }^{25}$ This indicates both that caution about the robustness of this finding is required and that further research is warranted.

\footnotetext{
${ }^{24}$ We thank the editor for this suggestion.

${ }^{25}$ These results can also be seen to fit with a new but growing literature on the effects of personal taxes on corporate choices including location (see for example Egger et al., 2013).
} 
For the effective corporate tax rate we find there are differences in the effect between small and large firms. In regression 12 we find no effect from the effective marginal rate on small firms but there is an effect for large firms in regression 13. This evidence is consistent with Egger et al. (2014). ${ }^{26}$

\section{[Insert Table 7]}

\subsection{The 2001 German Tax Reforms as a Natural Experiment}

As noted in the summary statistics in Section 3, for most of the countries that make up our sample the rate of corporate taxation was reduced occasionally and in relatively small steps. The exception to this is Germany where there was a large single reduction of just over 13 percentage points between 2000 and 2001 . The key features of the reforms were the replacement of the different tax rates on retained earnings (40\%) and distributed profits (30\%) with a single lower tax on all profits (25\%). When combined with local trading taxes, the statutory tax rate fell from $51.6 \%$ to $38.3 \%$ (Spengel, 2001). Becker et al. (2006) use this tax change as a 'natural experiment' to identify the effects of tax reform on the investment of foreign affiliates in Germany, finding significant and large effects. Becker et al. (2006) describe the motives behind this tax reform as aimed at attracting FDI and to adapt the German tax system to the rules of the EC Common Market. The motives behind the tax change therefore appear to be consistent with the view that the change in corporate tax rates was exogenous to firm productivity, in particular for small firms. ${ }^{27}$

Equation (2) which forms the model for estimation in this section, considers whether the corporate tax reforms affected productivity growth of small German firms compared to the pre-reform period (1999-2000). These growth effects are compared to a counterfactual of firms from Spain, Sweden and the UK. Small firms

\footnotetext{
${ }^{26}$ A possible reason why the effective marginal tax rate (EMTR) seems to be especially relevant to large firm's TFP convergence could be related to large firms conducting more $R \& D$. Where R\&D expenditures involve investment in intangible capital they will not generally be included in the Amadeus fixed capital data and hence are contained within TFP estimates. Unfortunately, without data on $\mathrm{R} \& \mathrm{D}$ expenditures and the EMTRs applicable to them, we are unable to test how far R\&D acts as a transmission mechanism from EMTRs to TFP. To the extent that EMTRs for equipment investment and EMTRs on R\&D are correlated, our EMTR variable could be picking up both effects.

${ }^{27}$ Our results using cross-country data in the previous sections of the paper are not dependent on the inclusion of Germany and therefore this large tax event in the data. When we exclude Germany, (see regression C6 in Appendix C), the results are unchanged.
} 
from these countries are chosen because the corporate tax rates remained unchanged in these countries over the years 1999 to 2002, whereas they changed in all other European countries. ${ }^{28}$

Invariably difference-in-difference regression estimates are scrutinized on the extent to which the control group represents the valid counterfactual: what would have happened in the absence of the tax reforms? To determine this we test whether productivity growth amongst small German firms was significantly different than that of small firms from Spain, Sweden and the UK in 1999 or 2000 conditional on the size of their initial TFP gap and any movements in the frontier. We find we cannot reject the null that the productivity growth rates were the same in the two groups, the t-statistic is equal to 0.01 . The parallel trend assumption would therefore appear to be satisfied.

Both of the tax variables have positive and statistically significant coefficients in regression 14 . Holding constant the tax rate across time, we find that firms that face higher tax rates grow less quickly for the same relative productivity ( $\beta_{4}$ is positive). This mirrors the findings in Tables 5 and 7 regarding the effects of taxation on the productivity growth of small firms. We also find additional effects from the tax reforms in Germany. Specifically, the results show that productivity within small German firms grew more quickly relative to the counterfactual in the period following the corporate tax reforms in Germany. Again this effect is increasing in the size of the productivity gap ( $\beta_{3}$ is positive).

Bertrand et al. (2004) note that a consequence of using difference-in-differences with data spanning several years, and where outcomes are serially correlated, is that the estimated standard errors will be inconsistent resulting in spurious inference. One solution suggested by Bertrand et al. (2004) is to collapse the data into a single pre- and post-treatment time period. We conduct this robustness test in regression 15, which accounts for the fall in the number of observations within the table compared to regression 14 . The pretreatment period is defined as the years 1999 and 2000 while the post-treatment period is 2001 and 2002. We therefore calculate the mean of each variable by firm-period and re-estimate the equation. Although the standard errors are somewhat larger when we use this approach, our results remain robust and highly

\footnotetext{
${ }^{28}$ The differences in the effect of corporate taxation between small and large firms reported in Table 5 and 7 suggest that large firms may also represent a valid counterfactual as they are unaffected by statutory corporate tax rates. We report regressions using large German firms as the counterfactual in Table C2 (regressions C9 to C11) in Appendix C. We continue to find that the productivity growth of small firms increased as a consequence of the reduction in tax rates.
} 
significant. ${ }^{29}$ How large are the effects that we estimate? Using the 13 percentage point reduction in corporate tax rates and the coefficient estimates from regression 15 , our results suggest for a small firm with a TFP level $85 \%(90 \%)$ of the frontier firm TFP growth was $1.5(1.0)$ percentage points higher compared to that predicted if corporate tax rates were left at 51 per cent.

\section{[Insert Table 8]}

In the remaining regressions of Table 8 we try to further establish the robustness of these findings, in particular to the effect of other tax changes. The counterfactual countries were chosen as they included no changes to corporate tax rates between 1999 and 2002. Corporate tax rates were however reduced in the UK in 1998 and there were changes in personal income tax rates in Germany and Sweden. In Germany the top rate of personal income tax was reduced from 53\% in 1999 to $51 \%$ in 2000 and again in 2001 to $48.5 \%$, while in Sweden it was reduced from $31 \%$ to $25 \%$ between 1999 and 2000 . There were also changes to the effective marginal corporate tax rate in Germany over this period, which fell by 9.3 percentage points between 1999 and 2000 and rose by 4.2 percentage points between 2000 and 2001. There were no changes to the effective marginal rate for Spain or Sweden and a small decrease of 0.7 percentage points between 1999 and 2000 in the UK.

To ensure that the effects of the changes to personal or effective marginal corporate tax rates do not contaminate our results in regression 16 we exclude UK firms from the counterfactual, and in regression 17 we exclude Sweden on the basis there was a change in the personal income tax rate. In regressions 18 and 19 we take a different approach to this issue and instead add measures of personal income tax rates (regressions 18 and 19) and the effective marginal rate (regression 19) used previously in regressions 11 to 13 in Table 7. Our main variables of interest are unaffected by controlling for other tax events in either the treatment country (Germany) or the counterfactual (Spain, Sweden and the UK). In all of the regressions we find that the reductions in the corporate tax rate in Germany increase productivity growth for small German firms. ${ }^{30}$

\footnotetext{
${ }^{29}$ There are 2,336 observations for German firms before 2000, 2,596 in 2001, and 2,808 in 2002.

${ }^{30}$ In an unreported regression we ran a placebo test that restricted the sample window to 1999 and 2000. We then created a placebo treatment (equal to 1 in 2000, 0 in 1999) and interacted this with the TFP gap variable. The coefficient on the interaction was insignificant indicating no pre-treatment trends or anticipation effects. We are unaware of any other non-tax policy changes that differ between Germany and the counterfactual countries over this period. The non-adoption of the Euro by the UK in 1999 may have had
} 


\section{Conclusions}

The role that government plays in encouraging productivity growth in firms has always attracted considerable academic interest. Much of this interest has however, been focused on those policy changes that foster changes in the extent of competition in an industry, either from foreign or other domestic firms. In this paper, we consider a more basic aspect of the policy environment of a country, the role of corporate taxation. The idea that taxation might affect productivity is not new, but its effects have typically only been examined as an indirect consequence of physical (tangible) capital or R\&D investments. In this paper we provide evidence on whether corporate marginal tax rates affect the returns to productivity enhancing investments, slowing the rate at which small firms catch-up with the best firms in their industry and country.

We find evidence consistent with this view. Higher rates of corporate taxation slow the rate of convergence for small firms, who are likely to be the most constrained from making productivity-enhancing investments. These results appear very robust to the addition of covariates to the regression, including those which account for differences in the steady-state level of productivity of firms. They are also robust to using the 2001 tax reform in Germany as a natural experiment. The results are therefore consistent with a causal interpretation from corporate taxation on the rate of convergence and suggest heterogeneity in the effects of taxation across firms. Small firms are affected, whereas large firms are not, and firms with a large productivity gap are more affected than firms with a small productivity gap. This highlights an important heterogeneity in the effects of taxation across countries, due to differences in the level of taxation, the number of smaller firms and the size of the TFP gap with the productivity frontier.

While a country's corporate tax policy is, and should be, influenced by numerous considerations, an important implication for corporate tax policy to emerge from this paper concerns the use of different statutory corporate rates for small versus large firms. In the UK and in Spain for example, the recent policy shift towards harmonisation of corporate tax rates between small and large firms (from a regime in which small firms faced lower rates) could adversely impact on the ability of smaller firms to catch-up on the productivity frontier.

some lagged effects on TFP compared to the other three countries but such effects, if they existed, seem likely to be minor for our results. 
Tables

Table 1: Number of Observations by Year

\begin{tabular}{|l|cccccccccc|c|}
\hline Year & 1996 & 1997 & 1998 & 1999 & 2000 & 2001 & 2002 & 2003 & 2004 & 2005 & Total \\
Obs. & 617 & 837 & 2,176 & 15,497 & 20,800 & 23,556 & 31,268 & 44,124 & 46,495, & 41,098 & 226,468 \\
\hline
\end{tabular}

Table 2: Population Summary Statistics

\begin{tabular}{lccc}
\hline & Observations & Mean & Std. Dev. \\
\hline Firm productivity growt ijct $_{\text {TFP growth of frontier }}$ jct & 226,468 & 0.027 & 0.180 \\
TFP relative to frontier firms jct $_{\text { }}$ & & 0.006 & 0.108 \\
\end{tabular}

Notes: TFP gap is measured as the ratio of productivity of firm $i$ over the productivity frontier in industry $j$, country $c$, in time period $t$. 
Table 3: TFP Relative to Frontier Firms by Country

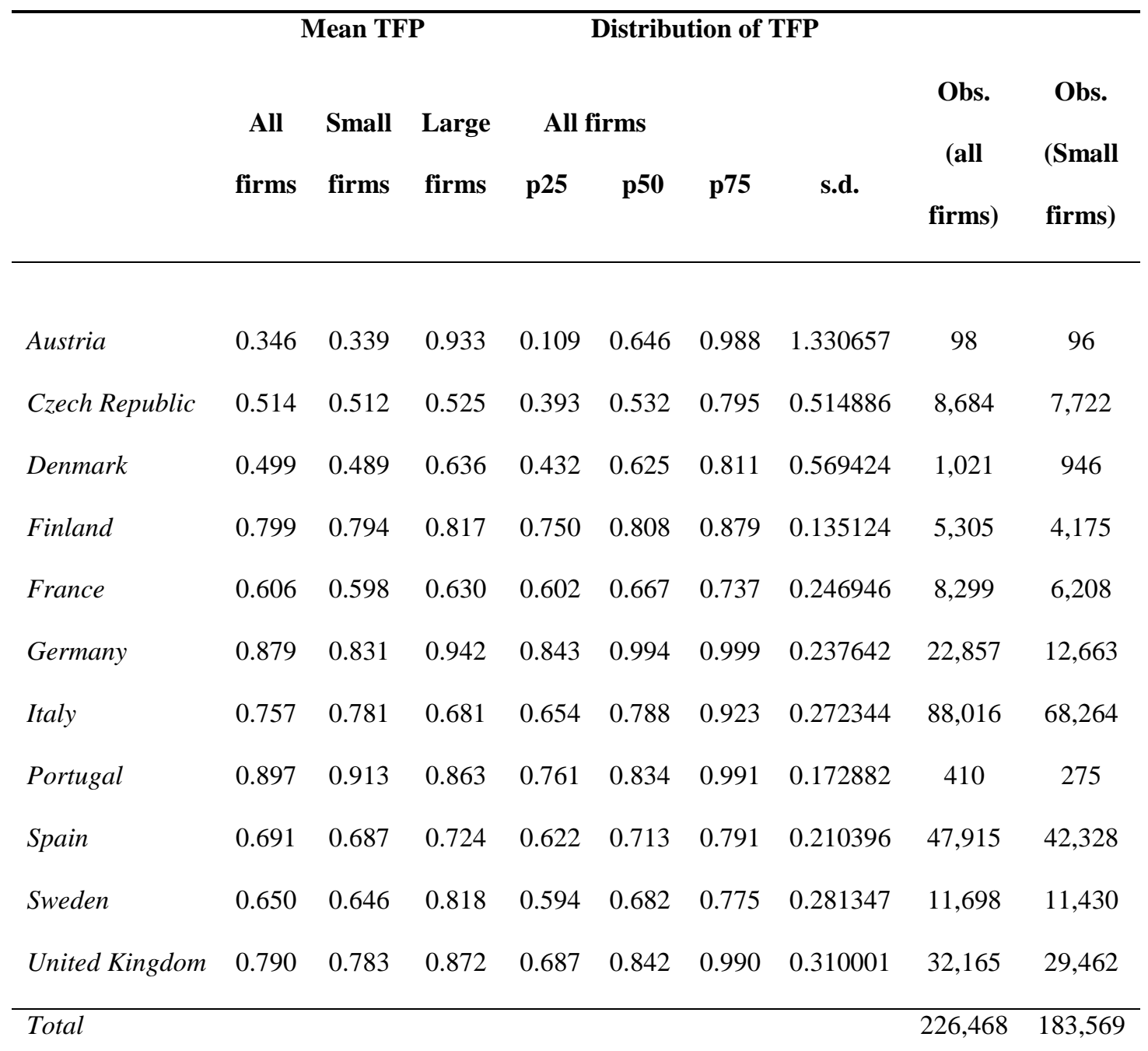

Notes: TFP is measured as the ratio of productivity of firm $i$ over the productivity frontier in industry $j, \operatorname{country} c$, in time period $t$. Small firms refers to employment less than 20 . 
Table 4: Corporate Tax Rates and Changes

\begin{tabular}{|c|c|c|c|c|c|c|}
\hline & $\begin{array}{c}\text { Statutory Corporate } \\
\text { Tax Rate (\%) }\end{array}$ & $\begin{array}{l}\text { Change 2005-1995 } \\
\text { (percentage points) }\end{array}$ & $\begin{array}{c}\text { Top Personal } \\
\text { Income } \\
\text { Tax Rate }(\%)\end{array}$ & $\begin{array}{l}\text { Change 2005-1995 } \\
\text { (percentage points) }\end{array}$ & $\begin{array}{c}\text { Effective Marginal } \\
\text { Tax Rate (\%) }\end{array}$ & $\begin{array}{l}\text { Change 2005-1995 } \\
\text { (percentage points) }\end{array}$ \\
\hline Austria & 33.18 & -9 & 50.00 & 0.00 & 17.73 & -4.73 \\
\hline Czech Republic & 33.36 & -15 & - & - & 14.62 & -4.68 \\
\hline Denmark & 32.00 & -6 & 42.39 & -37.00 & 19.91 & -3.44 \\
\hline Finland & 28.00 & 1 & 36.82 & -5.50 & 18.46 & 2.23 \\
\hline France & 37.14 & -6.7 & 50.64 & -8.80 & 18.94 & -0.59 \\
\hline Germany & 45.46 & -18 & 49.86 & -11.00 & 24.73 & -10.70 \\
\hline Italy & 43.27 & -14.9 & 47.36 & -5.00 & 17.57 & -8.60 \\
\hline Portugal & 35.00 & -12.1 & 40.00 & 0.00 & 15.14 & -6.99 \\
\hline Spain & 35.00 & 0 & 42.09 & -27.00 & 20.48 & -2.39 \\
\hline Sweden & 28.00 & 0 & 27.45 & -5.00 & 16.79 & 1.49 \\
\hline United Kingdom & 31.00 & -3 & 40.00 & 0.00 & 20.77 & -2.36 \\
\hline
\end{tabular}

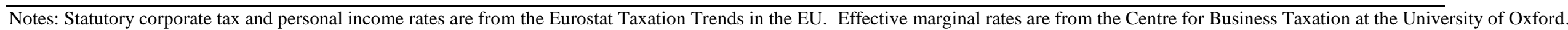

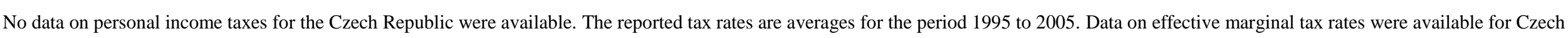
Republic for the years 2002 to 2005 and for Spain from 1996 to 2005 (the average and the change in taxation are measured across those years only). 
Table 5: Corporate Taxation and Productivity Convergence

\begin{tabular}{|c|c|c|c|c|c|c|c|c|}
\hline \multirow[t]{2}{*}{ Regression No. } & \multirow[b]{2}{*}{ All firms } & \multirow[b]{2}{*}{ Small firms } & \multirow[b]{2}{*}{ Large Firms } & \multirow{2}{*}{$\begin{array}{c}4 \\
\text { Employment } \\
<10\end{array}$} & \multirow{2}{*}{$\begin{array}{c}5 \\
\text { Employment } \\
<30\end{array}$} & \multirow{2}{*}{$\begin{array}{c}6 \\
\text { Employment } \\
<50\end{array}$} & \multirow{2}{*}{$\begin{array}{c}7 \\
\text { Olley-Pakes } \\
\text { TFP }\end{array}$} & \multirow{2}{*}{$\begin{array}{c}8 \\
\text { Wooldridge } \\
\text { TFP }\end{array}$} \\
\hline & & & & & & & & \\
\hline \multirow{2}{*}{ TFP growth of frontier ${ }_{j c t}\left(\alpha_{1}\right)$} & $0.343 * * *$ & $0.356^{* * *}$ & $0.280 * * *$ & $0.366^{* * *}$ & $0.348 * * *$ & $0.344 * * *$ & $0.116^{* * *}$ & $0.188 * * *$ \\
\hline & $(0.005)$ & $(0.006)$ & $(0.008)$ & $(0.006)$ & $(0.006)$ & $(0.006)$ & $(0.002)$ & $(0.007)$ \\
\hline \multirow[t]{2}{*}{ TFP gap $\left(\alpha_{2}\right)$} & $-0.417 * * *$ & $-0.434 * * *$ & $-0.371 * * *$ & $-0.504 * * *$ & $-0.435^{* * *}$ & $-0.427 * * *$ & $-0.211 * *$ & $-1.804 * * *$ \\
\hline & $(0.046)$ & $(0.053)$ & $(0.062)$ & $(0.057)$ & $(0.052)$ & $(0.051)$ & $(0.091)$ & $(0.331)$ \\
\hline \multirow[t]{2}{*}{ TFP gap $\times C T a x_{c t}\left(\alpha_{3}\right)$} & $0.368 * * *$ & $0.442 * * *$ & 0.069 & $0.640 * * *$ & $0.444 * * *$ & $0.436 * * *$ & $2.817 * * *$ & $2.040^{*}$ \\
\hline & $(0.090)$ & $(0.101)$ & $(0.164)$ & $(0.107)$ & $(0.100)$ & $(0.099)$ & $(0.296)$ & $(1.161)$ \\
\hline Additional Control Variables & $\sqrt{ }$ & $\sqrt{ }$ & $\sqrt{ }$ & $\sqrt{ }$ & $\sqrt{ }$ & $\sqrt{ }$ & $\sqrt{ }$ & $\sqrt{ }$ \\
\hline Fiscal \& profitability variables & $\sqrt{ }$ & $\sqrt{ }$ & $\sqrt{ }$ & $\sqrt{ }$ & $\sqrt{ }$ & $\sqrt{ }$ & $\sqrt{ }$ & $\sqrt{ }$ \\
\hline$\gamma_{C}, \gamma_{j}, \gamma_{t}$ & $\sqrt{ }$ & $\sqrt{ }$ & $\sqrt{ }$ & $\sqrt{ }$ & $\sqrt{ }$ & $\sqrt{ }$ & $\sqrt{ }$ & \\
\hline Observations & 226,468 & 183,569 & 42,899 & 161,824 & 187,648 & 192,375 & 72,132 & 37,625 \\
\hline
\end{tabular}

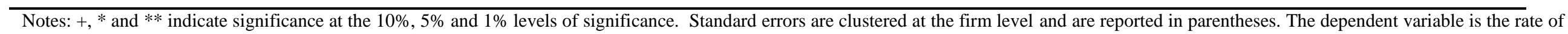

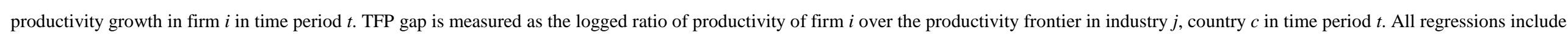

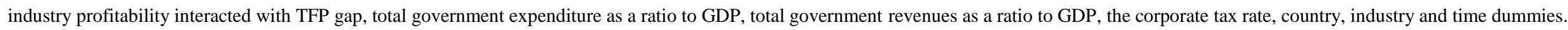


Table 6: Estimated Effects of Taxation on the Productivity Growth of Small Firms

\begin{tabular}{|l|c|c|c|c|c|}
\hline \multirow{2}{*}{ TFP (\% of frontier) } & \multicolumn{5}{|l|}{ Corporate Tax Rate } \\
& $\mathbf{2 5 \%}$ & $\mathbf{3 0 \%}$ & $\mathbf{3 5 \%}$ & $\mathbf{4 0 \%}$ & $\mathbf{4 5 \%}$ \\
\hline $75 \%$ & -0.43 & -0.87 & -1.30 & -1.73 & -2.17 \\
\hline $85 \%$ & -0.30 & -0.60 & -0.90 & -1.20 & -1.50 \\
\hline $95 \%$ & -0.19 & -0.39 & -0.58 & -0.78 & -0.97 \\
\hline
\end{tabular}

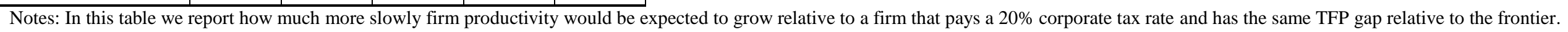

This table is based on the coefficient estimates from regression 2 (Table 5). 
Table 7: Robustness to Inclusion of Additional Control Variables and Alternative Tax Variables

\begin{tabular}{|c|c|c|c|c|c|}
\hline \multirow[t]{2}{*}{ Regression No. } & 9 & 10 & 11 & 12 & 13 \\
\hline & $\gamma_{i t}, \gamma_{j t}$ & FE model & Small firms & Small firms & Large firms \\
\hline \multirow{2}{*}{ TFP growth of frontier ${ }_{j c t}\left(\alpha_{1}\right)$} & $0.361 * * *$ & $0.634 * * *$ & $0.385 * * *$ & $0.377 * * *$ & $0.231 * * *$ \\
\hline & $(0.007)$ & $(0.007)$ & $(0.006)$ & $(0.006)$ & $(0.008)$ \\
\hline \multirow{2}{*}{ TFP gap $\left(\alpha_{2}\right)$} & $-0.456^{* * *}$ & $-1.855^{* * *}$ & $-0.740 * * *$ & $-0.627 * * *$ & $-0.982 * * *$ \\
\hline & $(0.053)$ & $(0.037)$ & $(0.061)$ & $(0.088)$ & $(0.100)$ \\
\hline \multirow[t]{2}{*}{$T F P g a p \times C \operatorname{Tax}_{c t}\left(\alpha_{3}\right)$} & $0.442 * * *$ & $2.727 * * *$ & $0.405 * * *$ & & \\
\hline & $(0.102)$ & $(0.112)$ & $(0.146)$ & & \\
\hline \multirow[t]{2}{*}{ TFPgap $\times$ PInc.Tax ${ }_{c t}$} & & & $0.009 * * *$ & $0.010 * * *$ & $0.005 * * *$ \\
\hline & & & $(0.001)$ & $(0.001)$ & $(0.002)$ \\
\hline \multirow[t]{2}{*}{ TFPgap $\times \mathrm{EMTR}_{c t}$} & & & & -0.173 & $2.691 * * *$ \\
\hline & & & & $(0.224)$ & $(0.275)$ \\
\hline Fiscal \& profitability variables & & $\sqrt{ }$ & $\sqrt{ }$ & $\sqrt{ }$ & $\sqrt{ }$ \\
\hline$\gamma_{C}, \gamma_{j}, \gamma_{t}$ & & & $\sqrt{ }$ & $\sqrt{ }$ & $\sqrt{ }$ \\
\hline Observations & 183,569 & 183,569 & 175,847 & 175,847 & 41,937 \\
\hline
\end{tabular}

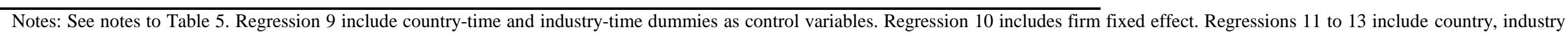

and time dummies and the personal income tax rate. Regressions 12 and 13 also includes the effective marginal tax rate. 
Table 8: Corporate Taxation and Productivity Convergence: German Tax Change

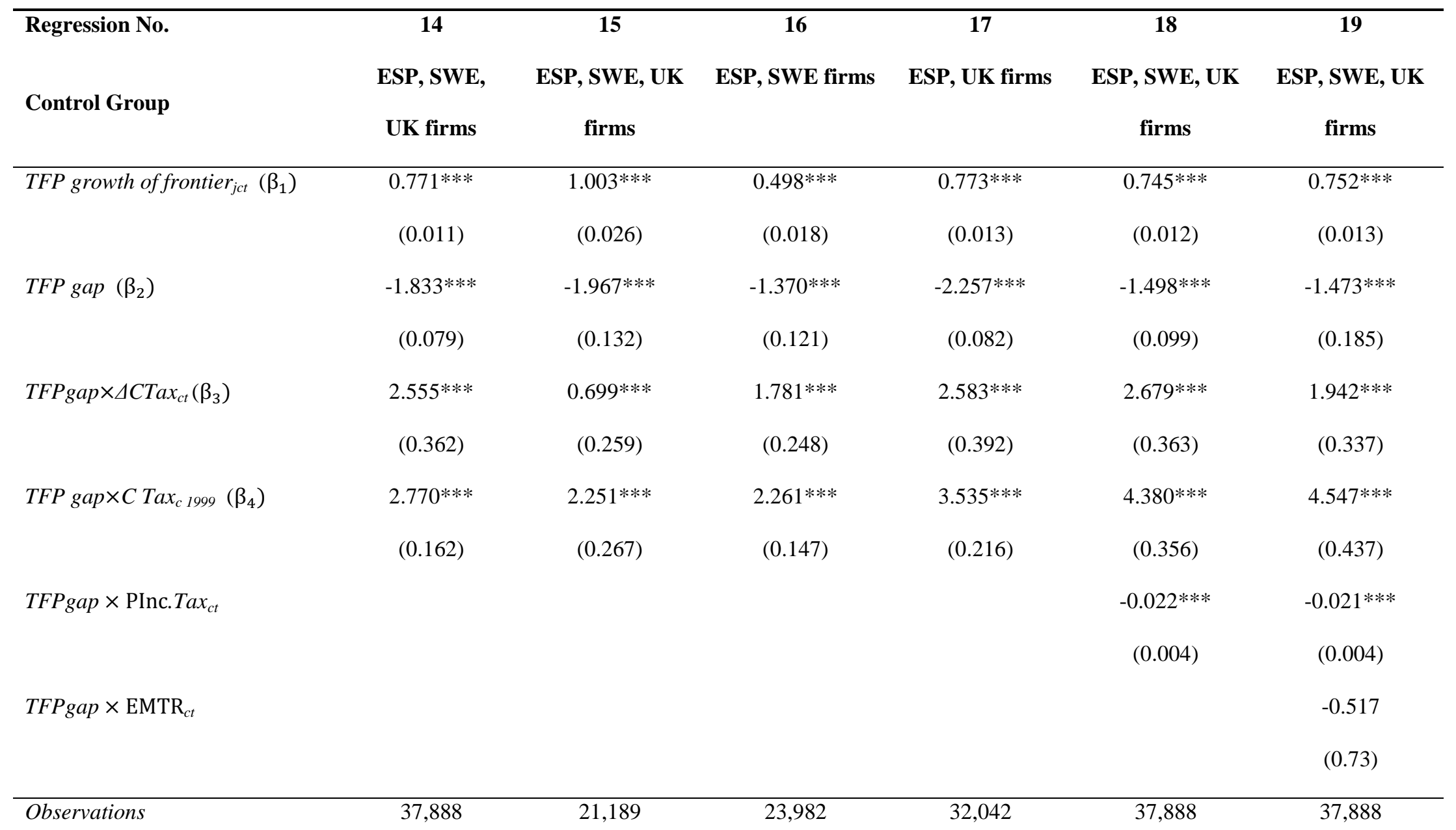

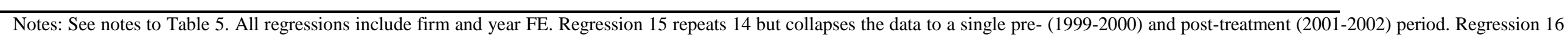

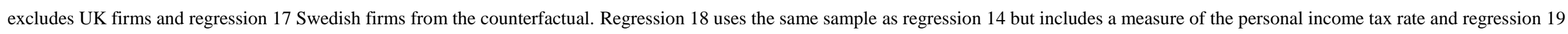
the effective marginal tax rate. Swe denotes small firms from Sweden, Spai firms from Spain and UK firms from the UK. Small German firms (the treatment group) are included in all regressions. 


\section{References}

Aghion, P., Fally, T. and Scarpetta, S. (2007). 'Credit Constraints as a Barrier to the Entry and Post Entry Growth of Firms: Theory and Evidence', Economic Policy, 22, p. 731-779.

António Alfonso \& Ana Sequeira, (2010). 'Revisiting business cycle synchronisation in the European Union', Working Papers Department of Economics 2010/22, ISEG - School of Economics and Management, Department of Economics, University of Lisbon.

Arnold, J. (2008). 'Do Tax Structures Affect Aggregate Economic Growth? Empirical Evidence from a Panel of OECD Countries', OECD Economics Department Working Paper 643.

Arnold, J. Brys, B., Heady, C., Johansson, A. Schwellnus, C. and Vartia, L. (2011). 'Tax Policy for Economic Recovery and Growth', The Economic Journal, Vol. 121, pp.F59-F80.

Arnold, J. Nicoletti, G. and Scarpetta, S. (2008). 'Regulation, Allocative Efficiency and Productivity in OECD Countries', OECD Working Papers No. 616.

Arrow, K.J. (1962), “Economic Welfare and the Allocation of Resources for Invention”, in: R.R. Nelson (ed.), The Rate and Direction of Inventive Activity, pp. 609-625, Princeton University Press, Princeton.

Auerbach, A. (2002). 'Taxation and Corporate Financial Policy' in Auerbach and M. Feldstein (eds.) Handbook of Public Economics Vol. 3. Amsterdam: north-Holland, 1251-1292.

Barro. R.J., Mankiw, N.G. and Sala-i-Martin, X. (1995). 'Capital Mobility in Neoclassical Models of Growth', American Economic Review, 85(1), p. 103-15.

Bartelsman, E. J., Haskel, J. and Martin, R. (2008). 'Distance to Which Frontier? Evidence on Productivity Convergence from International Firm-Level Data' CEPR Discussion Paper 7032.

Bartelsman, E.J., Haltiwanger, J. and Scarpetta, S. (2013). 'Cross-Country Difference in Productivity: The Role of Allocation and Selection', American Economic Review, 103(1), p. 305-334.

Beck, T. and Demirguc-Kunt, A. (2006). 'Small and Medium-Size Enterprises: Access to Finance as a Growth Constraint', Journal of Banking and Finance, 30(11), p. 2931-2943.

Beck, T., Demirguc-Kunt, A., Laeven, L. and Levine, R. (2008). 'Finance, Firm Size, and Growth', Journal of Money, Credit and Banking, 40(7), p. 1379-1405.

Becker, J., Fuest, C. and Hemmelgarn, T. (2006). 'Corporate Tax Reform and Foreign Direct Investment in Germany - Evidence from Firm-Level Data,' CESifo Working Paper Series 1722. 
Bertrand, M., Duflo, E. and Mullainathan, S. (2004) 'How Much Should We Trust Differences-in-Differences Estimates?', Quarterly Review of Economics, 119(1), p. 249-275.

Bleaney, M., Gemmell, N. and Kneller, R. (2001). 'Testing the Endogenous Growth Model: Public Expenditure, Taxation, and Growth over the Long Run', Canadian Journal of Economics, 34(1), p. 36-57. Bloom, N., and Van Reenen, J. (2010). 'Why Do Management Practices Differ across Firms and Countries?' Journal of Economic Perspectives, 24(1): 203-24.

Bloom, N., and Van Reenen, J. (2007). 'Measuring and Explaining Management Practices across Firms and Countries.' Quarterly Journal of Economics, 122(4): 1351-1408.

Bloom, N., Draca, M., and Van Reenen, J. (2011). 'Trade Induced Technical Change? The Impact of Chinese Imports on Innovation, IT and Productivity.' NBER Working Paper 16717.

Bloom, N., Lemos, R., Sadun, R., Scur, D. and Van Reenen, J. (2014). 'The new empirical economics of management', NBER Working Paper 20102.

Bond S., Hoeffler, A. and Temple, J. (2001). 'GMM Estimation of Empirical Growth Models,' Nuffield College Economics Papers 2001-W21, University of Oxford.

Brett, C. and Pinkse, J. (2000). 'The Determinants of Municipal Tax Rates in British Columbia', Canadian Journal of Economics, 33(3): 695-714.

Bridgman, B., Qi, S. and Schmitz, J.A. (2009). 'The Economic Performance of Cartels: Evidence from the New Deal U.S. Sugar Manufacturing Cartel, 1934-74.' Federal Reserve Bank of Minneapolis Report 437. Carroll, R., Holtz-Eakin, D. Rider,M. and Rosen, H, (2000b). 'Income Taxes and Entrepreneurs' Use of Labor.' Journal of Labor Economics, Vol. 18:2, p. 324-351.

Cummins, J. G., Hassett, K. A., \& Hubbard, G. R. (1994). ‘A Reconsideration of Investment Behavior Using Tax Reforms as Natural Experiments', Brookings Papers on Economic Activity, 2, p. 1-59.

Cummins, J. G., Hassett, K. A., \& Hubbard, G. R. (1996). 'Tax Reforms and Investment: A Cross-Country Comparison', Journal of Public Economics, 62, p. 1479-1505.

Da Rin, M., Di Giacomo, M., and Sembenelli, A. (2011). 'Entrepreneurship, Firm Entry, and the Taxation of Corporate Income: Evidence from Europe', Journal of Public Economics, 95(9-10), p. 1048-1066.

Degiannakis, S., Duffy, D. and Filis, G. (2014). 'Business Cycle Synchronization in EU: A Time-Varying Approach'. Scottish Journal of Political Economy, 61, p.348-370. 
Devereux, M.P. and Griffith, R. (2003). 'Evaluating Tax Policy for Location Decisions', International Tax and Public Finance, 10(2), p. 107-126.

Devereux, M.P., Griffith, R. and Klemm, A. (2002). 'Corporate Income Tax Reforms and International Tax Competition', Economic Policy,35, p.451-495.

Disney, R., Haskel, J. and Heden, Y. (2003). 'Restructuring and Productivity Growth in UK Manufacturing', Economic Journal, Vol. 113, pp. 666-94.

Djankov, S., Ganser, T., McLiesh, C., Ramalho, R. and Schleifer, A. (2010). ' The Effect of Corporate Taxes on Investment and Entrepreneurship', American Economic Journal: Macroeconomics, 2, p. 31-64.

Egger, P., Erhardt, K. and Keuschnigg, C. (2014). 'Heterogeneous Tax Sensitivity of Firm-Level Investments', University of St. Gallen Economics Working Paper Series 1426.

Egger, P., Pfaffermayr, M. and Winner, H. (2005a) 'An Unbalanced Spatial Panel Data Approach to US State Tax Competition', Economics Letters, 88(3), p. 329-335.

Egger, P., Pfaffermayr, M. and Winner, H. (2005b) 'Commodity Taxation in a "Linear" World: A Spatial Panel Data Approach', Regional Science and Urban Economics, 35(5), p. 527-541.

Egger, P., Radulescu, D. and Strecker, N. (2013). 'Effective labor taxation and the international location of headquarters,' International Tax and Public Finance, 20(4), p. 631-652.

Foster, L., J. Haltiwanger, and C. J. Krizan. (2001). 'Aggregate Productivity Growth: Lessons from Microeconomic Evidence.' In New Developments in Productivity Analysis, ed. Charles R. Hulten, Edwin R. Dean, and Michael J. Harper, 303-63. Chicago and London: University of Chicago Press.

Gayer, C. (2007). 'A fresh look at business cycle synchronisation in the euro area' European Economy. Economic Papers 287.

Gemmell, N., Kneller, R., and Sanz, I. (2011). 'The timing and persistence of fiscal policy impacts on growth: Evidence from OECD countries', The Economic Journal, 121, p. F33-F58.

Gemmell, N., Kneller, R., and Sanz, I. (2015). 'The growth effects of tax rates in the OECD', Canadian Journal of Economics, p. 1-39.

Görg, H. and Greenaway, D. (2004). 'Much Ado About Nothing? Do Domestic Firms Really Benefit from Foreign Direct Investment?' World Bank Research Observer, 19, p. 171-197. 
Griffith, R., Redding, S. and Van Reenen, J. (2003). 'R\&D and Absorptive Capacity: Theory and Empirical Evidence', Scandinavian Journal of Economics, 105(1), p.99-118.

Griffith, R., Redding, S. Simpson, H. (2009). 'Technological Catch-Up And Geographic Proximity,' Journal of Regional Science, 49(4), p. 689-720.

Hall, B. and Van Reenen, J., (2000). 'How Effective are Fiscal Incentives for R\&D? A review of the Evidence,' Research Policy, 29(4-5), p. 449-469.

Hassett, K. and Hubbard, G. (2002). 'Tax Policy and Business Investment', in A.J. Auerbach and M. Feldstein (eds.) Handbook of Public Economics Vol. 3. Amsterdam: north-Holland, p. 1293-1343.

Hines J.R.Jr., (2005). 'Do Tax Havens Flourish?,' NBER Chapters, in: Tax Policy and the Economy, Volume 19, pages 65-100 NBER.

House, C. and Shapiro, M, (2008). 'Temporary Investment Tax Incentives: Theory with Evidence from Bonus Depreciation', American Economic Review, 98(3), p. 737-768.

Hubbard, R.G. (1998). 'Capital-Market Imperfections and Investment', Journal of Economic Literature, 36(1), p. 193-225.

Kneller, R., Bleaney, M.F. and Gemmell, N. (1999). 'Fiscal Policy and Growth: Evidence from OECD Countries', Journal of Public Economics, 74(2), p. 171-190.

Lee, Y. and Gordon, R.H. (2005). 'Tax Structure and Economic Growth', Journal of Public Economics, 89(56), p. 1027-1043.

Levinsohn, J. and Petrin, A. (2003). 'Estimating Production Functions using Inputs to Control for Unobservables' Review of Economic Studies, 70(2), p. 317-342.

Masso, J., Merikull, J. and Vahter, P. (2013). 'Shift from Gross Profit Taxation to Distributed Profit Taxation: Are there Effects on Firms?', Journal of Comparative Economics, 41(4), p. 1092-1105.

Nickell, S. (1981). 'Biases in Dynamic Models with Fixed Effects', Econometrica, 49(6), p. 417-426.

Nicoletti, G., and Scarpetta, S. (2005). 'Regulation and Economic Performance: Product Market Reforms and Productivity in the OECD.' OECD Working Paper 460.

Olley, G. S., and Pakes, A. (1996). 'The Dynamics of Productivity in the Telecommunications Equipment Industry.' Econometrica, Vol. 64(6), p.1263-97. 
Pavcnik, N. (2002). 'Trade Liberalization, Exit, and Productivity Improvement: Evidence from Chilean Plants.' Review of Economic Studies, 69(1), p. 245-76.

Peretto, P.F. (2007). 'Corporate taxes, growth and welfare in a Schumpeterian economy', Journal of Economic Theory, 137, p. 353-382.

Petrin, A., and Sivadasan, J. (2010). 'Estimating Lost Output from Allocative Inefficiency, with Application to Chile and Firing Costs.' Unpublished.

Romer, C.D. and Romer, D.H. (2010). 'The Macroeconomic Effects of Tax Changes: Estimates Based on a New Measure of Fiscal Shocks', American Economic Review, 100(3), p. 763-801.

Romero-Avila, D. and Strauch, R. (2008). 'Public Finances and Long-Term Growth in Europe - Evidence from a Panel Data Analysis', European Journal of Political Economy, 24, p. 172-191.

Schmitz, J. A. (2005). 'What Determines Productivity? Lessons from the Dramatic Recovery of the U.S. and Canadian Iron Ore Industries following Their Early 1980s Crisis.' Journal of Political Economy, 113(3), p. $582-625$.

Spengel, C. (2001).'Der Steuerstandort Deutschland im Internationalen Vergleich, Eine Analyse Vor Dem Hintergrund Des Steuersenkungsgesetzes 2001, Expertise Für Den Sachverständigenrat Zur Begutachtung der Gesamtwirtschaftlichen Entwicklung, Universität Mannheim Working Paper.

Syverson, C. (2004). 'Market Structure and Productivity: A Concrete Example.' Journal of Political Economy, 112 (6), p. 1181-1222.

Syverson, C. (2011). 'What Determines Productivity?' Journal of Economic Literature, 49 (2), p.326-65.

Turnovsky, S.J. (2004). 'The Transitional Dynamics of Fiscal Policy: Long-Run Capital Accumulation and Growth', Journal of Money, Credit and Banking, 36(5), p. 883-910.

Wooldridge, J.M. (2009). 'On Estimating Firm-Level Production Functions Using Proxy Variables to Control for Unobservables', Economics Letters, 104(3), p. 112-114. 